\title{
The cumulative effects of forest disturbance and climate variability on baseflow in a large watershed in British Columbia, Canada
}

Qiang Li $^{1}$, Xiaohua Wei ${ }^{1 *}$, Mingfang Zhang ${ }^{2}$, Wenfei Liu ${ }^{3}$, Krysta Giles-Hansen ${ }^{1}$, Yi Wang ${ }^{1}$, Liangliang Duan ${ }^{4}$

$5 \quad{ }^{1}$ Department of Earth and Environmental Sciences, University of British Columbia Okanagan, 1177 Research Road, Kelowna, British Columbia, Canada, V1V 1V7

${ }^{2}$ School of Resources and Environment, University of Electronic Science and Technology of China, 2006 Xiyuan Ave. Chengdu, China, 611731

${ }^{3}$ Institute of Ecology and Environmental Science, Nanchang Institute of Technology, Nanchang, China

${ }^{4}$ School of Forestry, Northeast Forestry University, Harbin 150040, China

Correspondence to: Xiaohua Wei (adam.wei@ubc.ca)

Abstract. Assessing how forest disturbance and climate change affect baseflow or groundwater discharge is critical for understanding water resource supply and protecting aquatic functions. Previous studies have mainly evaluated the effects of forest disturbance on streamflow, with rare attention on baseflow, particularly in large watersheds. However, studying this topic is challenging as it requires explicit inclusion of climate into assessment due to their interactions at any large watersheds. In this study, we used Upper Similkameen River watershed (USR) $\left(1810 \mathrm{~km}^{2}\right)$, located in the southern interior 20 of British Columbia, Canada to examine how forest disturbance and climate variability affect baseflow. The conductivity mass balance method was first used for baseflow separation, and the modified double mass curves were then employed to quantitatively separate the relative contributions of forest disturbance and climate variability to annual baseflow. Our results showed that average annual baseflow 
Hydrol. Earth Syst. Sci. Discuss., doi:10.5194/hess-2016-291, 2016

Manuscript under review for journal Hydrol. Earth Syst. Sci.

Published: 20 June 2016

(c) Author(s) 2016. CC-BY 3.0 License.

(c) (i)
Hydrology and

and baseflow index (baseflow/streamflow) were about $85.2 \pm 21.5 \mathrm{~mm}_{\text {year }}{ }^{-1}$ and $0.22 \pm 0.05$ for the study period of 1954-2013, respectively. The forest disturbance increased the annual baseflow of 18.4 $\mathrm{mm}$, while climate variability decreased $19.4 \mathrm{~mm}$. In addition, forest disturbance also shifted the baseflow regime with increasing of the spring baseflow and decreasing of the summer baseflow. We

5 conclude that forest disturbance significantly altered the baseflow magnitudes and patterns, and its role in annual baseflow was equal to that caused by climate variability in the study watershed despite their opposite changing directions. The implications of our results are discussed in the context of future forest disturbance (or land cover changes) and climate changes.

Key words: Forest disturbance; Climate variability; Baseflow; Relative contributions.

\section{Introduction}

Increasing demands on groundwater resources highlights a critical need for improving knowledge in groundwater recharge and discharge (Scanlon et al., 2006; Uhlenbrook et al., 2002). Baseflow is a critical component in sustaining streamflow particularly during dry periods, and consequently is vital for aquatic

15 habitat and ecosystem functions (Power et al., 1999; Scanlon et al., 2006). Given the importance of baseflow, quantitative assessment of long-term baseflow and its contributing factors is necessary for understanding water balance, groundwater supply and aquatic functions. 
Hydrol. Earth Syst. Sci. Discuss., doi:10.5194/hess-2016-291, 2016

Manuscript under review for journal Hydrol. Earth Syst. Sci.

Published: 20 June 2016

(c) Author(s) 2016. CC-BY 3.0 License.

(c) (1)
Hydrology and

Earth System

Sciences

Discussions

In forest-dominant watersheds, the relationships of baseflow with forest and climate changes are usually inferred from the changes in groundwater tables, soil moisture, and streamflow discharges. Several reviews have summarized the effects of forest management on groundwater (Le Maitre et al., 1999; Price, 2011; Smerdon et al., 2009). The key finding is that after removal of vegetation cover, wetter soil moisture contents and higher groundwater tables are expected due to loss of evapotranspiration, while gain in vegetation cover results in lower groundwater tables. For example, a ten-year observational study in boreal forests in Eastern Canada showed that the water-table levels after 10-year disturbance were 5-7 $\mathrm{cm}$ higher than those of the pre-disturbance levels, but had reached nearly $50 \%$ of the pre-cut level (Marcotte et al., 2008). Clearly, forest changes can greatly affect groundwater recharge and consequently baseflow. However, most studies regarding the effects of forest disturbance on groundwater recharge or baseflow are conducted for a short period at the small watersheds scale. Direct and quantitative assessment on their long term and cumulative effects in the large watershed scale is rare (Le Maitre et al., 1999; Smerdon et al., 2009).

15 Climate variability is also another critical factor for influencing baseflow or groundwater recharge variations (Cao and Zheng, 2016; Fleming and Quilty, 2006; Squeo et al., 2006). Forest cover change and climate variability have been recognised as two major drivers influencing hydrological variations in forested watersheds. However, the integrated effects of forest disturbance and climate variability are largely dependent on their individual magnitudes and directions. To understand their individual effects, various approaches have been used and reviewed (Wei et al., 2013). The paired experimental approach is 
Hydrol. Earth Syst. Sci. Discuss., doi:10.5194/hess-2016-291, 2016

Manuscript under review for journal Hydrol. Earth Syst. Sci.

Published: 20 June 2016

(c) Author(s) 2016. CC-BY 3.0 License.

commonly used in small watersheds $\left(<10 \mathrm{~km}^{2}\right)$ for detecting the effects of forest changes on hydrology as it removes climatic influence, while statistical methods and modelling can be used to separate their relative contributions in large watersheds $\left(>1000 \mathrm{~km}^{2}\right)$ simply because the paired experimental approach is not applicable in large watersheds. Although there are growing studies on separating the relative effects

5 of forest change and climatic variability on hydrology, they are mainly on annual streamflow. As far as we know, there are no any studies to quantify the relative contributions of forest disturbance and climate to baseflow in large watersheds.

Direct and quantitative assessment on how baseflow or groundwater discharge responds to both forest and climate changes is a challenging subject. The first challenge is that there are no commonly-accepted methods for baseflow separation even though numerous methods have been developed. As compared with non-trace methods, trace-based methods have been receiving more attentions and applications (Li et al., 2014a; Miller et al., 2014). The tracer-based method uses mass balance to separate streamflow into two end-members: baseflow and surface runoff, based on their different flow paths. Because of longer

15 flow paths, baseflow normally has higher ion concentrations compared with surface runoff (Lott and Stewart, 2016; Matsubayashi et al., 1993; Stewart et al., 2007). Among trace-based methods, conductivity mass balance $(\mathrm{CMB})$ based on close correlations of ion concentration with water specific conductance (conductivity thereafter) is frequently used for baseflow separation. Conductivity data can be readily measured in the field, and is the most effective single parameter for separating surface runoff and ground 20 water contribution to stream (Caissie et al., 1996). As a result, conductivity has been widely used as the tracer for baseflow separation for agricultural watersheds (Li et al., 2014a; Zhang et al., 2013), urban 
Hydrol. Earth Syst. Sci. Discuss., doi:10.5194/hess-2016-291, 2016

Manuscript under review for journal Hydrol. Earth Syst. Sci.

Published: 20 June 2016

(c) Author(s) 2016. CC-BY 3.0 License.

(c) (i)
Hydrology and

Earth System

Sciences

Discussions

catchments (Pellerin et al., 2008), natural catchments (Covino and McGlynn, 2007; Miller et al., 2014;

Penna et al., 2014), and other environmental settings (Lott and Stewart, 2013; Stewart et al., 2007; Weijs

et al., 2013). However, CMB applications are constrained by long-term daily conductivity data, which are not normally available. To address this shortcoming, Miller et al. (2014) recently developed a regression-based model based on long term discrete conductivity and streamflow data, and then applied this model to estimate long-term continuous daily conductivity using streamflow data.

The second challenge is to separate relative contributions of forest disturbances and climate changes to baseflow in large forested watersheds. Various techniques including sensitivity-based, double mass curves, simple water balance, and time trend method have been developed for this purpose (Wei et al., 2013). Among them, Wei and Zhang, (2010) adopted modified double mass curves (MDMC) and time series analysis to separate the relative contributions of forest disturbance and climate change to streamflow. As the MDMC is based on water balance in any watersheds, it has the potential to separate the relative effects of forest disturbance and climate variability on baseflow.

The Upper Similkameen River watershed $\left(1810 \mathrm{~km}^{2}\right)$ is a large forest-dominated watershed located in the southern interior of British Columbia, Canada. Over the past a few decades, the watershed experienced various types of forest disturbances (e.g. logging, mountain pine beetle infestation, and wild fire). The cumulative forest disturbance accounts for about $30 \%$ of the total watershed area. The river is not regulated with long-term historic streamflow and climate data. Availability of long-term data, along with 
Hydrol. Earth Syst. Sci. Discuss., doi:10.5194/hess-2016-291, 2016

Manuscript under review for journal Hydrol. Earth Syst. Sci.

Published: 20 June 2016

(c) Author(s) 2016. CC-BY 3.0 License.

(c) (i)
Hydrology and

Earth System

Sciences

Discussions

severe forest disturbance provides an excellent opportunity to study the effects of forest disturbance and climate on baseflow. The key objectives of this study were: 1) to separate and characterize the long-term baseflow in the study watershed; 2) to quantify the relative contributions of forest disturbance and climate variability to baseflow; and 3) to discuss possible management implications of our results for water

5 resource supply and protection of aquatic functions.

\section{Study site and data}

\subsection{Study site}

The Upper Similkameen River at Princeton (USR) is about the $91 \mathrm{~km}$ in length and with a drainage area

10 of $1810 \mathrm{~km}^{2}$. It is located in the southern interior of British Columbia between the Coast Ranges Mountains and the Okanagan Valley, Canada. The elevation ranges from 630 to 2400 above sea level. The Similkameen River with its headwater in Manning Park drains to Okanogon River in U.S.A. The climate across the watershed is characterised by warm summers and cool winters. The watershed covers several biogeoclimatic zones including Interior Douglas Fir (IDF) zone on the valley floors and Montane

15 Spruce (MS) and Engelmann Spruce-Subalpine Fir (ESSF) at the higher elevations. The watershed is underlain by bedrock from several geologic ages. The bedrock types are generally resistant to water erosion, and form uplands and mountain ranges, which may contain bedrock aquifers, where are highly fractured. 
Hydrol. Earth Syst. Sci. Discuss., doi:10.5194/hess-2016-291, 2016

Manuscript under review for journal Hydrol. Earth Syst. Sci.

Published: 20 June 2016

(c) Author(s) 2016. CC-BY 3.0 License.

(c) (1)
Hydrology and

Figure 1. Location, streamflow network, and elevations of the study watershed with the total area of 1810 $\mathrm{km}^{2}$, of which $466 \mathrm{~km}^{2}$ is in USA

\subsection{Watershed data}

\subsubsection{Climate data}

Monthly mean, maximum and minimum temperatures, and precipitation of the study watershed were generated from the ClimateBC dataset (Wang et al., 2006). ClimateBC is a standalone program. It extracts and downscales PRISM (Daly et al., 2008) monthly climate normal data (800 x $800 \mathrm{~m})$ to scale-

10 free point locations, and calculates seasonal and annual climate variables for any specific locations based on latitude, longitude and elevation. Given the large spatial variations in climate, monthly climate data were derived at the resolution of $800 \times 800 \mathrm{~m}$, area-weighted climate data were finally derived for the study watershed.

15 Figure. 2. Long-term (1954-2013) average monthly precipitation, and monthly maximum and minimum temperatures in the Upper Similkameen River watershed. 
Hydrol. Earth Syst. Sci. Discuss., doi:10.5194/hess-2016-291, 2016

Manuscript under review for journal Hydrol. Earth Syst. Sci.

Published: 20 June 2016

(c) Author(s) 2016. CC-BY 3.0 License.

(c) (i)
Hydrology and

Earth System

Sciences

Discussions

\subsubsection{Forest disturbance data}

Two provincial databases: Cutblocks 2010 and Vegetation Resources Inventory (VRI) 2010 obtained from the British Columbia Ministry of Forests, Lands and Natural Resources Operations, Canada were used to quantify the forest disturbance history in the study watershed. The Cutblocks database records

5 forest harvesting sizes and timing, while VRI database provides detailed vegetation information including disturbance (i.e. fire, insect infestation, and logging), disturbance timing, biogeoclimatic zones, basal area, etc. Therefore, two databases are complementary and were used for this study.

\subsubsection{Hydrology and conductivity data}

10 Daily stream discharge data were gained from the hydrometric station (Station ID: 08NL007, Similkameen River at Princeton) operated and maintained by Environment Canada. The annual streamflow were sub-divided into three seasons: spring (March to May), summer (June-October) and fallwinter (November to February). The annual average discharge is $423 \mathrm{~mm}$ for the period of 1954 to 2013. The high discharges occurred in spring as a result of snow-melting account for $68 \%$ of the annual 15 discharges.

Specific conductance, streamflow temperature and other water quality data (e.g., copper, zinc, nitrogen and etc.) were collected in the Similkameen River at Princeton on the bridge of Highway 3 near the hydrometric station. Collection of water samples was started from 1966 by Environment Canada (Fig. 3).

20 There was, however, absence of 10-year $(1975-1984,1986)$ data collection. For this study a total of 823 
Hydrol. Earth Syst. Sci. Discuss., doi:10.5194/hess-2016-291, 2016

Manuscript under review for journal Hydrol. Earth Syst. Sci.

Published: 20 June 2016

(c) Author(s) 2016. CC-BY 3.0 License.

(c) (i)
Hydrology and

Earth System

Sciences

Discussions

samples from 1966 to 2013 were chosen. Specific conductance ranges from 47.4 to $274 \mu \mathrm{s} \mathrm{cm}^{-1}$. Also, insitu conductivity probe (CTD Diver, DI 271, Schlumberger Water Service, Canada) were installed in the hydrometric station to measure continuous conductivity at the frequency of 30 minutes from May 20, 2015 to September 14, 2016. The conductivity measurements for each day were averaged to derive daily 5 conductivity data.

Figure 3. Long term (1966-2013) discrete conductivity measurement and continuous streamflow discharge data in the Upper Similkameen River watershed.

\section{3. Methods}

\subsection{Quantifying forest disturbance levels}

Logging, Mountain Pine Beetle (MPB) infestation, and wildfire were three major forest disturbance types in the Similkameen River at Princeton (Figs. 4 and 5). According to VRI database, a forest stand in the study watershed was disturbed by either one type (i.e. logging or fire or MPB) or two types of disturbances

15 (logging + Fire or logging+ MPB). Two types of disturbances are defined as a forest stand which is first disturbed by one type followed by the other. A good example is that a forest stand is disturbed by fire first and then by salvage logging. 
Hydrol. Earth Syst. Sci. Discuss., doi:10.5194/hess-2016-291, 2016

Manuscript under review for journal Hydrol. Earth Syst. Sci.

Published: 20 June 2016

(c) Author(s) 2016. CC-BY 3.0 License.

(c) (i)
Hydrology and

Earth System

Sciences

Discussions

Different kinds of forest disturbances accumulate over space and time in any forested watersheds. Equivalent clear-cut area (ECA) used to quantify forest disturbance levels is defined as the area that has been clear-cut, fire-killed or infested by MPB, with a reduction factor (ECA coefficient) to account for hydrological recovery due to forest regeneration. An ECA coefficient of $100 \%$ means no hydrological recovery in a disturbed area, while an ECA coefficient of 0 indicates a full hydrological recovery. The cumulative clear-cut area (CECA) is the sum of annual ECA values. However, developing ECA data series within a watershed is complicated as hydrological recovery of a forest stand is determined by many factors including disturbance type, climate, and tree species. The detailed estimation of ECA can be found in Wei and Zhang, (2010) and Zhang and Wei, (2012).

Logging or post-disturbance salvage logging is the dominant disturbance type in the study watershed (Fig. 4). The largest logging occurred in 1991 with about $6.4 \%$ of the watershed area being harvested. Forest fire happened occasionally. The largest forest fire happened in 1984 with about $1 \%$ of the watershed area being disturbed. MPB was not a significant disturbance type until 2003 . About $1 \%$ and $1.7 \%$ of the 15 watershed area were affected by MPB in 2004 and 2007, respectively. Up to year 2011, the cumulative equivalent clear cut area (CECA) was $30 \%$ of the total watershed area (Fig. 5). The CECA sharply increased by $8 \%$ after the significant logging in 1991. The CECA was then mainly driven by MPB since 2003. In summary, the watershed was heavily disturbed. 
Hydrol. Earth Syst. Sci. Discuss., doi:10.5194/hess-2016-291, 2016

Manuscript under review for journal Hydrol. Earth Syst. Sci.

Published: 20 June 2016

(c) Author(s) 2016. CC-BY 3.0 License.

(c) (i)
Hydrology and

Figure 4. Annual disturbed area (\% of the watershed) in the Upper Similkameen River watershed from 1960 to 2011.

Figure 5. Cumulative Equivalent Clear-cut Area (CECA) in the Upper Similkameen River watershed

5 from 1960 to 2011.

\subsection{Baseflow separation}

\subsubsection{Conductivity mass balance (CMB) method}

Daily baseflow data were estimated by the conductivity mass balance (CMB) method, which is expressed

as:

$$
B F=Q \frac{C_{q}-C_{r o}}{C_{b f}-C_{r o}}
$$

where, $B F$ is baseflow $\left(\mathrm{m}^{3} \mathrm{~s}^{-1}\right) ; Q$ is daily streamflow discharge $\left(\mathrm{m}^{3} \mathrm{~s}^{-1}\right) ; C_{q}$ is the conductivity of streamflow $\left(\mu \mathrm{S} \mathrm{cm}^{-1}\right) ; C_{b f}$ is the conductivity of baseflow $\left(\mu \mathrm{S} \mathrm{cm}^{-1}\right)$; and $C_{r o}$ is the conductivity of surface runoff $\left(\mu \mathrm{S} \mathrm{cm} \mathrm{cm}^{-1}\right) . B F I$ is the baseflow index defined as baseflow / streamflow. $C_{r o}$ representing 15 conductivity in streamflow is mainly from surface runoff (i.e. highest flow), while $C_{b f}$ is mainly contributed from baseflow (i.e. lowest flow). Assumptions of applying the CMB method are: 1) contributions from other end-members are negligible; 2) $C_{b f}$ and $C_{r o}$ are constant over the specific period; and 3) $C_{b f}$ and $C_{r o}$ are different from each other (Miller et al., 2014; Stewart et al., 2007). 
Hydrol. Earth Syst. Sci. Discuss., doi:10.5194/hess-2016-291, 2016

Manuscript under review for journal Hydrol. Earth Syst. Sci.

Published: 20 June 2016

(c) Author(s) 2016. CC-BY 3.0 License.

(c) (i)
Hydrology and

\subsubsection{Estimation of daily conductivity}

Discrete conductivity data are highly related to daily discharges (Fig. 6). Previous studies indicated that conductivity was also related to time and other variables that describe seasonality and variability in stream

5 discharges (Miller et al., 2015). A general regression model is showed in Equation (2). This model is characterised with two merits in estimation conductivity. First, it adopts Fourier series to explain seasonality, which reflects the reality and is consistent with snow-melt dominated watersheds. Second, flow anomalies describe flow variability at different time scales. Those two merits add explanatory power and enhance estimation confidence. The model development was constructed in $\mathrm{R}$ software ( $\mathrm{R}$ Development Team, 2014).

$$
\begin{aligned}
& \ln C=I+\beta_{1} \ln Q+\beta_{1} T+\beta_{2} \sin (2 \pi T)+\beta_{3} \cos (2 \pi T) \\
& +\beta_{4} \sin (4 \pi T)+\beta_{5} \operatorname{Cos}(4 \pi T)+\beta_{6} F A
\end{aligned}
$$

where, $\beta_{\mathrm{i}}$ is coefficient of model parameters; $\mathrm{C}$ is daily specific conductance $\left(\mu \mathrm{S} \mathrm{cm}^{-1}\right)$; $\mathrm{I}$ is the intercept of model; $\mathrm{Q}$ is daily discharge $\left(\mathrm{m}^{3} \mathrm{~s}^{-1}\right), \mathrm{T}$ is time expressed as decimal years (e.g. 1999.40 = May 26, 1999); and $(\sin (2 \pi T)+\cos (2 \pi T))$ and $(\sin (2 \pi T)+\cos (2 \pi T)+\sin (4 \pi T)+\cos (4 \pi T))$ is simple Fourier

15 series that explains annual seasonality with one and two concentration annual peaks. FA is flow anomalies (dimensionless). It is calculated from measured daily discharges that describe variability in streamflow at different time scales (e.g. 1-year, 30-day, and 1-day). FA is calculated through R package (Ryberg and Vecchia, 2012). 
Hydrol. Earth Syst. Sci. Discuss., doi:10.5194/hess-2016-291, 2016

Manuscript under review for journal Hydrol. Earth Syst. Sci.

Published: 20 June 2016

(c) Author(s) 2016. CC-BY 3.0 License.

(c) (i)
Hydrology and

Earth System

Sciences

Discussions

The best model was evaluated by coefficient of determination $\left(\mathrm{R}^{2}\right)$, Nash-Sutcliffe Coefficient $\left(\mathrm{E}_{\mathrm{n}-\mathrm{s}}\right)$, and significance of $P$ values of each modelled variable. The plots of model residuals and fitted values, such as normal probability plots of model residuals, were also evaluated. The model achieving the best performance in the calibration was chosen. The chosen model was then validated with the in-situ

5 continuous conductivity measurement. If the model achieves good estimation with the measured conductivity data, it was then employed as the final model to estimate the continuous conductivity data for baseflow separation ( $\mathrm{Li}$ et al., 2014b).

Figure 6. The relationship between streamflow conductivity (Y) and streamflow discharge (X) in the Upper Similkameen River watershed.

\subsubsection{Selection of $\mathbf{C}_{b f}$ and $\mathbf{C}_{r o}$}

The accuracy of baseflow estimation in the CMB method is highly dependent on the selection of two parameters $\left(\mathrm{C}_{\mathrm{bf}}\right.$ and $\left.\mathrm{C}_{\mathrm{ro}}\right)$. Like other baseflow separation methods, all contributed end-members are lumped into two broadly components (i.e. baseflow and surface runoff). Separation of a hydrograph into

15 two end-members is more appropriate for large watersheds $\left(>1000 \mathrm{~km}^{2}\right)$, as compared with smaller watersheds where more than two-members should be considered (Uhlenbrook et al., 2002). In addition, Zhang et al. (2013) reported that baseflow is more sensitive to $C_{b f}$ rather than $C_{r o}$ in the small snowdominated watershed $\left(14.5 \mathrm{~km}^{2}\right)$. Also, in-situ conductivity measurements in 14 large watersheds $(>1000$ $\mathrm{km}^{2}$ ) indicated that the constant $C_{r o}$ might not have large impacts on the baseflow (Miller et al., 2015). 20 The annual paired $\mathrm{C}_{\mathrm{bf}}$ and $\mathrm{C}_{\mathrm{ro}}$ were selected for each water year (i.e. August to September) to minimize 
Hydrol. Earth Syst. Sci. Discuss., doi:10.5194/hess-2016-291, 2016

Manuscript under review for journal Hydrol. Earth Syst. Sci.

Published: 20 June 2016

(c) Author(s) 2016. CC-BY 3.0 License.

(c) (i)
Hydrology and

Earth System

Sciences

Discussions

temporal variations in conductivity. Conductivities corresponding to 0.01 and 0.99 quantile flow rates (i.e. flow exceeds at $1 \%$ and $99 \%$ of the time in a given year) in one year were averaged and treated as annual $\mathrm{C}_{\mathrm{bf}}$ and $\mathrm{C}_{\mathrm{ro}}$, respectively.

\subsection{Cross correlations analysis}

Cross correlations analysis is an effective and widely used method to test if there are significant relationships among time series variables. Its advantage is that it can remove autocorrelations existing in data series and identify lagged causality between two data series (Zhang and Wei, 2014). In this study, it was adopted to detect the relationships and lagged effects between forest disturbance and hydrological variables. All the tested hydrological variables and forest disturbance data were pre-whitened to remove the autocorrelation by fitting the ARIMA (Autoregressive Integrated Moving Average) models. Model residuals from ARIMA models with best performance, achievements of model stationary and coefficient of determination were selected for cross-correlation tests (Liu et al., 2015a).

\subsection{Quantification of relative contributions of forest disturbance and climatic variability to}

\section{baseflow}

Forest disturbance and climate variability are commonly considered as the two major drivers for hydrological variations in large forested watersheds. The modified double mass curves (MDMC) were normally used to quantify the relative contributions of forest disturbance and climatic variability to annual

20 streamflow (Liu et al., 2015a; Zhang and Wei, 2012; Zhang et al., 2012). To quantify the relative 
Hydrol. Earth Syst. Sci. Discuss., doi:10.5194/hess-2016-291, 2016

Manuscript under review for journal Hydrol. Earth Syst. Sci.

Published: 20 June 2016

(c) Author(s) 2016. CC-BY 3.0 License.

(c) (i)
Hydrology and

contributions of forest disturbance and climatic variability to baseflow in this study, we applied the same approaches as we did for annual streamflow. The details for assessing the relative contributions of forest disturbance and climatic variability to annual streamflow are described in (Liu et al., 2015a; Wei and Zhang, 2010; Zhang and Wei, 2012; Zhang et al., 2012).

Streamflow is divided into surface runoff $(R O)$ and baseflow $(B F)$. Theoretically, water balance in large watersheds can be expressed as: $P=E T+R O+B F(3 \mathrm{a})$ or $B F=P-E T-R O(3 \mathrm{~b})$. The effective groundwater discharge $\left(G_{e}\right)$ is then defined as the difference between precipitation, evapotranspiration, and surface runoff. A liner relationship is assumed between accumulative baseflow $\left(B F_{a}\right)$ and accumulative effective groundwater discharge $\left(G_{e}\right)$. Thus, MDMC can be modified by plotting $B F_{a}$ against cumulative $G_{e}$. Breaking points can be identified on the MDMC if there are significant influences from non-climatic variables. Thus, the relative effects of forest disturbance and climatic variability on baseflow can be quantified. Relative contributions of forest disturbance and climate change to baseflow can be calibrated as:

$$
\begin{aligned}
& R_{f}=\frac{\left|\Delta Q_{f}\right|}{\left|\Delta Q_{f}\right|+\left|\Delta Q_{c}\right|} \times 100 \% \\
& R_{c}=\frac{\left|\Delta Q_{c}\right|}{\left|\Delta Q_{f}\right|+\left|\Delta Q_{c}\right|} \times 100 \%
\end{aligned}
$$


Hydrol. Earth Syst. Sci. Discuss., doi:10.5194/hess-2016-291, 2016

Manuscript under review for journal Hydrol. Earth Syst. Sci.

Published: 20 June 2016

(c) Author(s) 2016. CC-BY 3.0 License.

(c) (i)
Hydrology and

Earth System

Sciences

Discussions

where, $R_{f}$ and $R_{c}$ are the relative contributions of forest disturbance and climate variability to baseflow, respectively. $\Delta Q_{f}$ and $\Delta Q_{c}$ are the deviations of annual baseflow caused by only forest disturbance and climate change, respectively.

In this study, monthly potential evapotranspiration (PET) was estimated through Eqn. (6) and then used to calculate actual evapotranspiration (ET) by both Eqns. (7) and (8). The final monthly ET estimates were averaged from those two methods or equations.

$$
\begin{aligned}
& P E T=0.0023 R_{a}\left[\frac{T_{\max }+T_{\min }}{2}+17.8\right]\left(T_{\max }-T_{\min }\right)^{0.5} \\
& E T=\left\{P[1-\exp (-P E T / P] \times P E T \times \tanh (P / P E T)\}^{0.5}\right. \\
& E T=P \frac{1+\omega(P E T / P)}{1+\omega(P E T / P)+P / P E T}
\end{aligned}
$$

where, Eqns. (6), (7), and (8) are Hargreaves (Hargreaves and Allen, 2003), Budydo (Budyko, 1974) and Zhang (Zhang et al., 2001), respectively. $R_{a}$ is extraterrestrial radiation $\left(\mathrm{MJ} \mathrm{m}^{-2}\right)$; PET is potential evapotranspiration (mm); $T_{\max }$ and $T_{\min }$ are maximum and minimum temperature $\left({ }^{\circ} \mathrm{C}\right) ; P$ is precipitation $(\mathrm{mm}) ;$ ET is actual evapotranspiration $(\mathrm{mm}) ; w$ plant-available water coefficient ( $w=2$ used for this study).

\section{4. Results}

\subsection{Baseflow from regression-based conductivity estimation}

The parameters of the conductivity estimation model were finalized as: logarithm of streamflow discharge $(\operatorname{Ln} Q)$, timing $(T)$, two concentration peaks of Fourier series $(\sin (2 \pi T)+\cos (2 \pi T)+\sin (4 \pi T)+\cos$ 
Hydrol. Earth Syst. Sci. Discuss., doi:10.5194/hess-2016-291, 2016

Manuscript under review for journal Hydrol. Earth Syst. Sci.

Published: 20 June 2016

(c) Author(s) 2016. CC-BY 3.0 License.

(c) (i)
Hydrology and

Earth System

Sciences

Discussions

$(4 \pi \mathrm{T})$ ), and flow anomalies (FA) with time scales of 1 year, 30 days and 1 day. The coefficients of the regression model variables were listed in Table 1 . The diagnostic statistics including $\mathrm{R}^{2}$ and $\mathrm{E}_{\mathrm{n}-\mathrm{s}}$ between the simulated and observed conductivity values are 0.87 and 0.86 , respectively. The established regression model was then used to calculate conductivity (sample size: 118) from May 20, 2015 to

5 September 14, 2015 for validating the model performance. The $\mathrm{R}^{2}$ is 0.91 , while the root mean squared error is $17.8 \mu \mathrm{s} \mathrm{cm}^{-1}$ and $\mathrm{E}_{\mathrm{n}-\mathrm{s}}$ is 0.91 . The results suggest that the regression model can be reasonably well used to estimate continuous conductivity.

Using the established model, we estimated that average annual baseflow rate and BFI (baseflow index) were $85.2 \pm 21.5 \mathrm{~mm}_{\text {year }}{ }^{-1}$ and $0.22 \pm 0.05$ for the period of 1954-2013, respectively (Fig. 7). The lowest and highest baseflow rates were $41.8 \mathrm{~mm}_{\text {year }}^{-1}$ in 1993 and $127.1 \mathrm{~mm}_{\text {year }}{ }^{-1}$ in 1972 , respectively, while the lowest and highest BFI were 0.14 in 1971 and 0.35 in 2001, respectively. The higher monthly baseflow rates were found in the snow-melting seasons (e.g., April $\left(10.8 \mathrm{~mm} \mathrm{month}^{-1}\right)$ and May (13.5 mm month 1)) (Fig. 8).

Table 1. Summary of the regression model for conductivity estimation

Figure 7. Long-term annual mean streamflow, baseflow, and baseflow index (BFI) in the Upper Similkameen River watershed from 1954 to 2013. 
Hydrol. Earth Syst. Sci. Discuss., doi:10.5194/hess-2016-291, 2016

Manuscript under review for journal Hydrol. Earth Syst. Sci.

Published: 20 June 2016

(c) Author(s) 2016. CC-BY 3.0 License.

(c) (i)
Hydrology and

Earth System

Sciences

Discussions

Figure 8. Long-term monthly streamflow, baseflow, and baseflow index (BFI) in the Upper Similkameen River watershed from 1954 to 2013.

\subsection{Cross-correlations between CECA and hydrological variables}

The cross-correlations between the CECA and hydrological variables in Table 2 showed that forest disturbance had significantly affected hydrological variables. Forest disturbance significantly increased the annual and spring baseflows, but it significantly decreased the summer baseflow. No significant impacts of forest disturbance on winter baseflow were found in the study watershed.

Table 2. Cross-correlations between cumulative equivalent clear-cut area (CECA) and hydrological variables

\subsection{Quantification of the relative effects of forest disturbance and climate on annual baseflow}

15 Only one breaking point (year 1972) was detected in the MDMC for baseflow (Fig. 9). The fitted ARIMA intervention test for the slope of MDMC also showed the significant intervention occurred in 1972 (Table 3). The whole study period was, therefore, divided into the reference period (1954-1972) and the disturbed period (1973-2013). As shown in Fig. 9, in the reference period, a straight line indicated that cumulative annual baseflow changes were consistent with cumulative groundwater discharge variations. For the 
Hydrol. Earth Syst. Sci. Discuss., doi:10.5194/hess-2016-291, 2016

Manuscript under review for journal Hydrol. Earth Syst. Sci.

Published: 20 June 2016

(c) Author(s) 2016. CC-BY 3.0 License.

(c) (i)
Hydrology and

Earth System

Sciences

Discussions

disturbed period, the distinct shift in 1972 was found between the observed and predicted cumulative baseflow, indicating the significant effects of forest disturbance on baseflow. For a better explanation of temporal variations of those effects, the disturbed period were subsequently sub-divided into five periods listed in Table 4.

Fig. 10 also shows large annual baseflow deviations ranging from -127.5 to $306.9 \mathrm{~mm}$ across those five disturbed periods. In addition, $\mathrm{R}_{\mathrm{f}}$ to baseflow steadily increased with the CECA increase. With the forest disturbance level of $2.31 \%$ in the period of 1973 to 1982 , climate variability was the dominate factor for the annual baseflow variations, and its relative contribution accounts for $62.5 \%$ (or $13.3 \mathrm{~mm}$ ) of the total annual baseflow variations. The effects of forest disturbance on baseflow then became dominate with the CECA increase in the period of 1993 to 2013. Overall, forest disturbance increased annual baseflow of $18.4 \mathrm{~mm}$, while climate variability decreased $19.4 \mathrm{~mm}$ in the disturbance period (1973-2013). Our result also clearly demonstrate that forest disturbance and climate variability played a co-equal role for baseflow with $\mathrm{R}_{\mathrm{f}}$ and $\mathrm{R}_{\mathrm{c}}$ being $48.8 \%$ and $51.2 \%$ of the total baseflow variations, respectively.

Figure 9. Modified Double Mass Curve of cumulative annual baseflow vs. cumulative groundwater discharge

Table 3. ARIMA Intervention for the slope of MDMC for baseflow 
Hydrol. Earth Syst. Sci. Discuss., doi:10.5194/hess-2016-291, 2016

Manuscript under review for journal Hydrol. Earth Syst. Sci.

Published: 20 June 2016

(c) Author(s) 2016. CC-BY 3.0 License.

(c) (1)
Hydrology and

Earth System

Sciences

Discussions

Figure 10. Annual variations of the effects of forest disturbance on annual baseflow in the Upper Similkameen River watershed from 1973 to 2013.

Table 4. Relative contributions of forest disturbance and climate variability to annual baseflow in the Upper Similkameen River watershed from 1973 to 2013.

\section{Discussions}

\subsection{Baseflow estimation}

Our baseflow separation results from the tracer-based method show that average annual baseflow rate and BFI were $85.2 \pm 21.5 \mathrm{~mm} \mathrm{year}^{-1}$ and $0.22 \pm 0.05$ for the period of 1954-2013, respectively. Those 10 estimates are comparable with groundwater recharges estimated by other studies in the study region. For examples, annual recharge rate in Grand Folks is about $135.46 \mathrm{~mm}_{\text {year }}^{-1}$ (precipitation: $471 \mathrm{~mm}$ ) calculated through the groundwater model validation (Allen et al., 2004). Average annual recharge rates are $88 \mathrm{~mm}$ (precipitation: $447 \mathrm{~mm}$ ) in Vernon (Liggett and Allen, 2010) and $77.8 \pm 50.8 \mathrm{~mm}$ (precipitation at $496.5 \pm 77.9 \mathrm{~mm}$ ) in Deep Creek watershed, northern Okanagan (Assefa and Woodbury,

15 2013). Given the spatial variations in climate, land use and geology, our estimations on baseflow are acceptable in our study watershed. 
Hydrol. Earth Syst. Sci. Discuss., doi:10.5194/hess-2016-291, 2016

Manuscript under review for journal Hydrol. Earth Syst. Sci.

Published: 20 June 2016

(c) Author(s) 2016. CC-BY 3.0 License.

(c) (1)
Hydrology and

Earth System

Sciences

Discussions

\subsection{The cumulative effects of forest disturbance on annual baseflow}

Over the disturbed period of 1973-2013, the average increment of annual baseflow attributed to forest disturbance was $18.4 \mathrm{~mm}$, which accounted for $30.8 \%$ of total annual baseflow. The baseflow changes were low for the period of 1973 to 1982 when the forest disturbance level was small $(2.31 \%)$. The baseflow increased dramatically after 1991 with the significant logging happened in 1991 and the mountain pine beetle infestation broke out in 2003. Clearly, the cumulative forest disturbance in the study watershed significantly increased annual baseflow. Such increasing is likely due to increasing of soil water storages and consequent groundwater recharging as a result of less evapotranspiration caused by forest disturbance.

Our results on the effects of forest disturbance on annual baseflow are consistent with other studies. For examples, after the native forest removal, the groundwater recharge increased from 1.5 to $6 \mathrm{~mm}_{\text {year }}{ }^{-1} \mathrm{in}$ a large watershed $\left(1250 \mathrm{~km}^{2}\right)$ located in the west Australia (Leaney and Herceg, 1995). Clearing the native vegetation in the Murry River basin has increased the recharge from $<0.1 \mathrm{~mm}$ to $0.2 \mathrm{~mm}^{-1}$ year $^{-1}$ to 3 to 30 mm year-1 (Barnett, 1990). In the central interior of British Columbia, Canada, Rex and Dubé, (2006) concluded that the groundwater level has been elevated by $10 \mathrm{~cm}$ following by forest harvest than mountain pine beetle infestation. In Vancouver Island, Canada, the groundwater table has been increased 30-50 cm after 10 years of logging (Hetherington, 1998). Despite those consistent results in terms of changing directions, there are large variations in changing magnitudes. This is because of the differences 20 in climate, spatial heterogeneity of geologic and soil conditions, groundwater storage, and forest disturbance levels among those studied watersheds. Therefore, that the effects of forest disturbance on 
Hydrol. Earth Syst. Sci. Discuss., doi:10.5194/hess-2016-291, 2016

Manuscript under review for journal Hydrol. Earth Syst. Sci.

Published: 20 June 2016

(c) Author(s) 2016. CC-BY 3.0 License.

(c) (i)
Hydrology and

Earth System

Sciences

Discussions

baseflow are likely watershed specific and more case studies are needed to develop general conclusions regarding the relationship between forest changes and baseflow.

As mentioned in the introduction, previous studies on the similar topic often took an indirect approach to assess the effects of forest change on baseflow, and consequently there is a general lack of quantitative and direct assessment on the cumulative effects of forest disturbance on baseflow. In this study, our MDMC framework was successfully applied to quantify the long term cumulative effects of forest disturbance on baseflow, which can be extended to other watershed studies where similar data are available. The MDMC framework has been successfully employed to separate the effects of climate and vegetation changes on annual streamflow in different climatic regions (Liu et al., 2015a; Yao et al., 2012; Zhang et al., 2012). It was our first application of this framework on separating the relative effects of forest disturbance and climate change on annual baseflow. To implement this methodology for assessing forest disturbance and baseflow, we need to generate a relative accurate baseflow data series. In this study, we used the objective tracer-based method for baseflow separation, which minimized the uncertainties in

15 baseflow separation methods. In addition, long term data on climate, hydrology and forest change must be available in any study watersheds where forests experience significant changes (e.g., disturbance or reforestation) so that their significant hydrological effects can be detected. 
Hydrol. Earth Syst. Sci. Discuss., doi:10.5194/hess-2016-291, 2016

\subsection{The cumulative effects of forest disturbance on seasonal baseflow}

Cross-correlation results revealed that forest disturbance has altered the baseflow regimes, specifically, increased spring baseflow while decreased summer baseflow in our watershed (Table 3). Similar results have been found in other studies (e.g. Robinson and Dupeyrat, 2005; Eisenbies et al., 2007). This is likely

5 due to higher rates of snow accumulation and melting following forest disturbance (Winkler et al., 2015). Such increases may add additional water sources for spring baseflow but reduce water recharging for summer baseflow because forest disturbance may advance the snow melting timing. Thus, the baseflow in summer was relatively reduced as compared to those in the pre-disturbance periods. The similar results were also reported by the paired experimental watersheds (Winkler et al., 2015) and the hydrological modelling study (Schnorbus and Alila, 2013) in the same region.

Low flow (baseflow) in dry seasons has been receiving growing attentions due to increased demands. In snow-dominated watersheds, forest disturbance increased low flow in Baker River watershed $\left(1560 \mathrm{~km}^{2}\right)$, while no significant changes on low flow were found in Willow River watershed $\left(3185 \mathrm{~km}^{2}\right)$ with a similar

15 level of forest disturbance (Zhang et al., 2015). In rain-dominated watersheds, deforestation reduced the low flows by 30\% in Meijiang watershed (6983 $\mathrm{km}^{2}$ ) (Liu et al., 2015b). Bruijnzeel, (2004) reviewed several studies in tropical regions indicating that forest harvesting decreased the low flow in dry seasons. Zhou et al. (2010) found that the low flow in dry seasons has been significantly increased by reforestation in Guangdong Province $\left(179752 \mathrm{~km}^{2}\right)$, subtropical of China. The above inconsistent results indicate that

20 low flow responses to forest change are highly variable as they are not only related to the level of forest changes but also the alteration of soil conditions. 


\subsection{Offsetting effects of forest disturbance and climate change on baseflow}

Various studies have showed that forest disturbance and climate change can play offsetting effects on annual streamflow (Wei and Zhang, 2010; Zhang et al., 2012). Our study also demonstrated that forest disturbance and climate variability played similar roles on annual baseflow, but with opposite directions: forest disturbance increased annual baseflow, while climate variability decreased it in the study period. However, there are temporal variations in relative contributions of forest disturbance to annual baseflow depending on the levels of forest disturbance. In our study, we found that the impacts of forest disturbance on baseflow are larger than those from climate change in the periods of 1993-2013, while smaller in the periods of 1973-1992. The similar results were also reported by other studies. For example, the study conducted in the Nebraska Sand Hills, USA found that land use change is more significant than climate change on baseflow (Wang and Cai, 2010). A comprehensive study by Juckem et al. (2008) found that climate change has advanced baseflow timing, while land cover change significantly altered the baseflow quantity.

The effects of forest disturbance and climatic variability on annual baseflow can also be additive. While offsetting effects lead to less variation in water resource, additive effects can cause river flows to either increase (e.g., higher chances of floods) or decease (e.g., higher chances of droughts). Thus, when managing any watersheds for future water resources, forest changes, climate variability and their interactions should be carefully considered. 


\subsection{Implications of forest disturbance on watershed management}

Groundwater is important for maintaining aquatic ecosystems and providing critical water supply in dry periods (Power et al., 1999). Although forest disturbance increased annual mean baseflow, it significantly

5 reduced summer baseflow when water demands are the most in the study region. The reduced summer baseflow, along with higher temperature in the summer can intensify the pressures on aquatic systems, which may negatively affect the habitat and life stages of various salmon fish species in the study watershed (Hyatt et al., 2003). In addition, the reduced summer baseflow will also intensify competitions on water resources between human demand and those for maintaining aquatic functions. On the other

10 side, with consideration of the water scarcity in the region, the forest disturbance increased the annual baseflow, which can attenuate the water stress in the region caused by climate change. Thus, forest disturbance, climate and their interactions must be carefully managed in order to sustain water supply for human being as well as for aquatic functions.

\section{6. Conclusions}

Quantifying the long term and cumulative effects of forest disturbance on baseflow has rarely been reported in the literature. From this study, we conclude that forest disturbance significantly increased annual baseflow, while climate variability decreased it. In addition, forest disturbance also altered seasonal baseflow patterns by increasing the spring baseflow and decreasing the summer baseflow. All 
Hydrol. Earth Syst. Sci. Discuss., doi:10.5194/hess-2016-291, 2016

Manuscript under review for journal Hydrol. Earth Syst. Sci.

Published: 20 June 2016

(c) Author(s) 2016. CC-BY 3.0 License.

(c) (i)
Hydrology and

Earth System

Sciences

Discussions

those hydrological effects on baseflow have important implications for protecting water supply and aquatic systems, which should be carefully managed.

\section{Acknowledgements}

5 We thank the British Columbia Ministry of Forests, Lands and Natural Resources Operations for providing forest inventory data. Thanks are also given to Environment Canada for their streamflow and conductivity data. The funding for supporting this project was provided by the Regional District of Okanagan-Similkameen through a contract.

\section{References}

10 Allen, D. M., Mackie, D. C., and Wei, M.: Groundwater and climate change: a sensitivity analysis for the Grand Forks aquifer, southern British Columbia, Canada, Hydrogeol J, 12, 270-290, 10.1007/s10040003-0261-9, 2004.

Assefa, K. A., and Woodbury, A. D.: Transient, spatially varied groundwater recharge modeling, Water Resour Res, 49, 4593-4606, 10.1002/wrcr.20332, 2013.

15 Barnett, S.: Effect of Land Clearance in the Mallee Region on River Murray Salinity and Land Salinisation, BMR Journal of Australian Geology \& Geophysics BJAGDT, 11, 205-208, 1990.

Bruijnzeel, L. A.: Hydrological functions of tropical forests: not seeing the soil for the trees?, Agr Ecosyst Environ, 104, 185-228, 10.1016/j.agee.2004.01.015, 2004. 
Hydrol. Earth Syst. Sci. Discuss., doi:10.5194/hess-2016-291, 2016

Manuscript under review for journal Hydrol. Earth Syst. Sci.

Published: 20 June 2016

(c) Author(s) 2016. CC-BY 3.0 License.

(c) (i)
Hydrology and

Earth System

Sciences

Discussions

Budyko, M.I., (1974), Climate and Life, Int. Geophys. Series, Vol. 18, Academic Press, New York and London p. 508.

Caissie, D., Pollock, T. L., and Cunjak, R. A.: Variation in stream water chemistry and hydrograph separation in a small drainage basin, J Hydrol, 178, 137-157, Doi 10.1016/0022-1694(95)02806-4, 1996.

Cao, G. L., and Zheng, C. M.: Signals of short-term climatic periodicities detected in the groundwater of North China Plain, Hydrol Process, 30, 515-533, 10.1002/hyp.10631, 2016.

Covino, T. P., and McGlynn, B. L.: Stream gains and losses across a mountain-to-valley transition: Impacts on watershed hydrology and stream water chemistry, Water Resour Res, 43, Artn W1043110.1029/2006wr005544, 2007.

Daly, C., Halbleib, M., Smith, J. I., Gibson, W. P., Doggett, M. K., Taylor, G. H., Curtis, J., and Pasteris, P. P.: Physiographically sensitive mapping of climatological temperature and precipitation across the conterminous United States, Int J Climatol, 28, 2031-2064, 10.1002/joc.1688, 2008.

Eisenbies, M. H., Aust, W. M., Burger, J. A., and Adams, M. B.: Forest operations, extreme flooding events, and considerations for hydrologic modeling in the Appalachians - A review, Forest Ecol Manag, 242, 77-98, 10.1016/j.foreco.2007.01.051, 2007.

Fleming, S. W., and Quilty, E. J.: Aquifer responses to El Nino-Southern Oscillation, Southwest British Columbia, Ground Water, 44, 595-599, 10.1111/j.1745-6584.2006.00187.x, 2006. 
Hydrol. Earth Syst. Sci. Discuss., doi:10.5194/hess-2016-291, 2016

Manuscript under review for journal Hydrol. Earth Syst. Sci.

Published: 20 June 2016

(c) Author(s) 2016. CC-BY 3.0 License.

(c) (i)
Hydrology and

Earth System

Sciences

Discussions

Hargreaves, G. H., and Allen, R. G.: History and evaluation of Hargreaves evapotranspiration equation, J Irrig Drain E-Asce, 129, 53-63, 10.1061/(Asce)0733-9437(2003)129:1(53), 2003.

Hetherington, E. :Watershed hydrology. In Carnation Creek and Queen Charlotte Islands fish/forestry watershed workshop: Applying 20 years of costal research to management solutions. D. L. Hogan, P.J. Tschplinski, and S. Chatwin (editors), BC Ministry of Forests, Victoria, British Columbia. pp. 33-40, 1998.

Hyatt, K. D., Stockwell, M. M., and Rankin, D. P.: Impact and adaptation responses of Okanagan River sockeye salmon (Oncorhynchus nerka) to climate variation and change effects during freshwater migration: stock restoration and fisheries management implications, Can Water Resour J, 28, 689$713,2003$.

Juckem, P. F., Hunt, R. J., Anderson, M. P., and Robertson, D. M.: Effects of climate and land management change on streamflow in the driftless area of Wisconsin, J Hydrol, 355, 123-130, 2008.

Le Maitre, D. C., Scott, D. F., and Colvin, C.: A review of information on interactions between vegetation and groundwater, Water Sa, 25, 137-152, 1999.

15 Leaney, F., and Herczeg, A.: Regional recharge to a karst aquifer estimated from chemical and isotopic composition of diffuse and localised recharge, South Australia, J Hydrol, 164, 363-387, 1995.

Li, Q., Qi, J. Y., Xing, Z. S., Li, S., Jiang, Y. F., Danielescu, S., Zhu, H. Y., Wei, X. H., and Meng, F. R.: An approach for assessing impact of land use and biophysical conditions across landscape on 
Hydrol. Earth Syst. Sci. Discuss., doi:10.5194/hess-2016-291, 2016

Manuscript under review for journal Hydrol. Earth Syst. Sci.

Published: 20 June 2016

(c) Author(s) 2016. CC-BY 3.0 License.

(c) (i)
Hydrology and

Earth System

Sciences

Discussions

recharge rate and nitrogen loading of groundwater, Agr Ecosyst Environ, 196, 114-124, 10.1016/j.agee.2014.06.028, 2014a.

Li, Q., Xing, Z. S., Danielescu, S., Li, S., Jiang, Y. F., and Meng, F. R.: Data requirements for using combined conductivity mass balance and recursive digital filter method to estimate groundwater recharge in a small watershed, New Brunswick, Canada, J Hydrol, 511, 658-664, 10.1016/j.jhydrol.2014.01.073, 2014b.

Liggett, J. E., and Allen, D. M.: Comparing approaches for modeling spatially distributed direct recharge in a semi-arid region (Okanagan Basin, Canada), Hydrogeol J, 18, 339-357, 10.1007/s10040-0090512-5, 2010.

Liu, W. F., Wei, X. H., Fan, H. B., Guo, X. M., Liu, Y. Q., Zhang, M. F., and Li, Q.: Response of flow regimes to deforestation and reforestation in a rain-dominated large watershed of subtropical China, Hydrol Process, 29, 5003-5015, 10.1002/hyp.10459, 2015a.

Liu, W. F., Wei, X. H., Liu, S. R., Liu, Y. Q., Fan, H. B., Zhang, M. F., Yin, J. M., and Zhan, M. J.: How do climate and forest changes affect long-term streamflow dynamics? A case study in the upper reach of Poyang River basin, Ecohydrology, 8, 46-57, Doi 10.1002/Eco.1486, $2015 \mathrm{~b}$.

Lott, D. A., and Stewart, M. T.: A Power Function Method for Estimating Base Flow, Ground Water, 51, 442-451, 10.1111/j.1745-6584.2012.00980.x, 2013.

Lott, D. A., and Stewart, M. T.: Base flow separation: A comparison of analytical and mass balance methods, J Hydrol, 535, 525-533, 10.1016/j.jhydrol.2016.01.063, 2016. 
Hydrol. Earth Syst. Sci. Discuss., doi:10.5194/hess-2016-291, 2016

Manuscript under review for journal Hydrol. Earth Syst. Sci.

Published: 20 June 2016

(c) Author(s) 2016. CC-BY 3.0 License.

(c) (i)
Hydrology and

Earth System

Sciences

Discussions

Marcotte, P., Roy, V., Plamondon, A. P., and Auger, I.: Ten-year water table recovery after clearcutting and draining boreal forested wetlands of eastern Canada, Hydrol Process, 22, 4163-4172, 10.1002/hyp.7020, 2008.

Matsubayashi, U., Velasquez, G. T., and Takagi, F.: Hydrograph Separation and Flow-Analysis by Specific Electrical Conductance of Water, J Hydrol, 152, 179-199, Doi 10.1016/00221694(93)90145-Y, 1993.

Miller, M. P., Susong, D. D., Shope, C. L., Heilweil, V. M., and Stolp, B. J.: Continuous estimation of baseflow in snowmelt-dominated streams and rivers in the Upper Colorado River Basin: A chemical hydrograph separation approach, Water Resour Res, 50, 6986-6999, 10.1002/2013WR014939, 2014.

Miller, M. P., Johnson, H. M., Susong, D. D., and Wolock, D. M.: A new approach for continuous estimation of baseflow using discrete water quality data: Method description and comparison with baseflow estimates from two existing approaches, J Hydrol, 522, 203-210, 10.1016/j.jhydrol.2014.12.039, 2015.

Pellerin, B. A., Wollheim, W. M., Feng, X. H., and Vorosmarty, C. J.: The application of electrical conductivity as a tracer for hydrograph separation in urban catchments, Hydrol Process, 22, 18101818, 10.1002/hyp.6786, 2008.

Penna, D., Engel, M., Mao, L., Dell'Agnese, A., Bertoldi, G., and Comiti, F.: Tracer-based analysis of spatial and temporal variations of water sources in a glacierized catchment, Hydrol Earth Syst Sc, 18, 5271-5288, 10.5194/hess-18-5271-2014, 2014. 
Hydrol. Earth Syst. Sci. Discuss., doi:10.5194/hess-2016-291, 2016

Manuscript under review for journal Hydrol. Earth Syst. Sci.

Published: 20 June 2016

(c) Author(s) 2016. CC-BY 3.0 License.

(c) (i)
Hydrology and

Earth System

Sciences

Discussions

Power, G., Brown, R. S., and Imhof, J. G.: Groundwater and fish - insights from northern North America, Hydrol Process, 13, 401-422, Doi 10.1002/(Sici)1099-1085(19990228)13:3<401::AidHyp746>3.3.Co;2-1, 1999.

Price, K.: Effects of watershed topography, soils, land use, and climate on baseflow hydrology in humid regions: A review, Prog Phys Geog, 35, 465-492, 2011.

Rex, J., and Dubé, S.: Predicting the risk of wet ground areas in the Vanderhoof Forest District: Project description and progress report, Journal of Ecosystems and Management, 7, 2006.

Robinson, M., and Dupeyrat, A.: Effects of commercial timber harvesting on streamflow regimes in the Plynlimon catchments, mid-Wales, Hydrol Process, 19, 1213-1226, 10.1002/hyp.5561, 2005.

10 Ryberg, K. R., and Vecchia, A. V.: waterData--An R package for retrieval, analysis, and anomaly calculation of daily hydrologic time series data, version 1.0, US Geological Survey2331-1258, 2012.

Scanlon, B. R., Keese, K. E., Flint, A. L., Flint, L. E., Gaye, C. B., Edmunds, W. M., and Simmers, I.: Global synthesis of groundwater recharge in semiarid and arid regions, Hydrol Process, 20, 33353370, 10.1002/hyp.6335, 2006.

15 Schnorbus, M., and Alila, Y.: Peak flow regime changes following forest harvesting in a snow-dominated basin: Effects of harvest area, elevation, and channel connectivity, Water Resour Res, 49, 517-535, 10.1029/2012WR011901, 2013.

Smerdon, B. D., Redding, T., and Beckers, J.: An overview of the effects of forest management on groundwater hydrology, Journal of Ecosystems and Management, 10, 2009. 
Hydrol. Earth Syst. Sci. Discuss., doi:10.5194/hess-2016-291, 2016

Manuscript under review for journal Hydrol. Earth Syst. Sci.

Published: 20 June 2016

(c) Author(s) 2016. CC-BY 3.0 License.

(c) (i)
Hydrology and

Earth System

Sciences

Discussions

Squeo, F. A., Aravena, R., Aguirre, E., Pollastri, A., Jorquera, C. B., and Ehleringer, J. R.: Groundwater dynamics in a coastal aquifer in north-central Chile: Implications for groundwater recharge in an arid ecosystem, J Arid Environ, 67, 240-254, 10.1016/j.jaridenv.2006.02.012, 2006.

Stewart, M., Cimino, J., and Ross, M.: Calibration of base flow separation methods with streamflow conductivity, Ground Water, 45, 17-27, 10.1111/j.1745-6584.2006.00263.x, 2007.

Uhlenbrook, S., Frey, M., Leibundgut, C., and Maloszewski, P.: Hydrograph separations in a mesoscale mountainous basin at event and seasonal timescales, Water Resour Res, 38, Artn 1096 10.1029/2001wr000938, 2002.

Wang, D. B., and Cai, X. M.: Comparative study of climate and human impacts on seasonal baseflow in urban and agricultural watersheds, Geophys Res Lett, 37, Artn L0640610.1029/2009g1041879, 2010.

Wang, T., Hamann, A., Spittlehouse, D. L., and Aitken, S. N.: Development of scale-free climate data for western Canada for use in resource management, Int J Climatol, 26, 383-397, Doi 10.1002/Joc.1247, 2006.

Wei, X. H., and Zhang, M. F.: Quantifying streamflow change caused by forest disturbance at a large spatial scale: A single watershed study, Water Resour Res, 46, Doi 10.1029/2010wr009250, 2010.

Wei, X. H., Liu, W. F., and Zhou, P. C.: Quantifying the Relative Contributions of Forest Change and Climatic Variability to Hydrology in Large Watersheds: A Critical Review of Research Methods, Water-Sui, 5, 728-746, Doi 10.3390/W5020728, 2013. 
Hydrol. Earth Syst. Sci. Discuss., doi:10.5194/hess-2016-291, 2016

Manuscript under review for journal Hydrol. Earth Syst. Sci.

Published: 20 June 2016

(c) Author(s) 2016. CC-BY 3.0 License.

(c) (i)
Hydrology and

Earth System

Sciences

Discussions

Weijs, S. V., Mutzner, R., and Parlange, M. B.: Could electrical conductivity replace water level in rating curves for alpine streams?, Water Resour Res, 49, 343-351, 10.1029/2012WR012181, 2013.

Winkler, R., Spittlehouse, D., Boon, S., and Zimonick, B.: Forest disturbance effects on snow and water yield in interior British Columbia, Hydrol Res, 46, 521-532, 10.2166/nh.2014.016, 2015.

Yao, Y. F., Cai, T. J., Wei, X. H., Zhang, M. F., and Ju, C. Y.: Effect of forest recovery on summer streamflow in small forested watersheds, Northeastern China, Hydrol Process, 26, 1208-1214, Doi 10.1002/Hyp.8204, 2012.

Zhang, L., Dawes, W. R., and Walker, G. R.: Response of mean annual evapotranspiration to vegetation changes at catchment scale, Water Resour Res, 37, 701-708, Doi 10.1029/2000wr900325, 2001.

10 Zhang, L., Zhao, F. F., Chen, Y., and Dixon, R. N. M.: Estimating effects of plantation expansion and climate variability on streamflow for catchments in Australia, Water Resour Res, 47, Artn W12539.10.1029/2011wr010711, 2011.

Zhang, M., and Wei, X.: The effects of cumulative forest disturbance on streamflow in a large watershed in the central interior of British Columbia, Canada, Hydrol Earth Syst Sc, 16, 2021-2034, DOI 10.5194/hess-16-2021-2012, 2012.

Zhang, M., Wei, X., and Li, Q.: A quantitative assessment on the response of flow regimes to cumulative forest disturbances in large snow-dominated watersheds in the interior of British Columbia, Canada, Ecohydrology, 2015. 
Hydrol. Earth Syst. Sci. Discuss., doi:10.5194/hess-2016-291, 2016

Manuscript under review for journal Hydrol. Earth Syst. Sci.

Published: 20 June 2016

(c) Author(s) 2016. CC-BY 3.0 License.

(c) (i)
Hydrology and

Zhang, M. F., Wei, X. H., Sun, P. S., and Liu, S. R.: The effect of forest harvesting and climatic variability on runoff in a large watershed: The case study in the Upper Minjiang River of Yangtze River basin, J Hydrol, 464, 1-11, DOI 10.1016/j.jhydrol.2012.05.050, 2012.

Zhang, M. F., and Wei, X. H.: Contrasted hydrological responses to forest harvesting in two large neighbouring watersheds in snow hydrology dominant environment: implications for forest management and future forest hydrology studies, Hydrol Process, 28, 6183-6195, Doi 10.1002/Hyp.10107, 2014.

Zhang, R. G., Li, Q., Chow, T. L., Li, S., and Danielescu, S.: Baseflow separation in a small watershed in New Brunswick, Canada, using a recursive digital filter calibrated with the conductivity mass balance method, Hydrol Process, 27, 2659-2665, 10.1002/hyp.9417, 2013.

Zhou, G. Y., Wei, X. H., Luo, Y., Zhang, M. F., Li, Y. L., Qiao, Y. N., Liu, H. G., and Wang, C. L.: Forest recovery and river discharge at the regional scale of Guangdong Province, China, Water Resour Res, 46, Artn W0950310.1029/2009wr008829, 2010. 
Hydrol. Earth Syst. Sci. Discuss., doi:10.5194/hess-2016-291, 2016

Manuscript under review for journal Hydrol. Earth Syst. Sci.

Published: 20 June 2016

(c) Author(s) 2016. CC-BY 3.0 License.
Hydrology and

(c) $($ i)

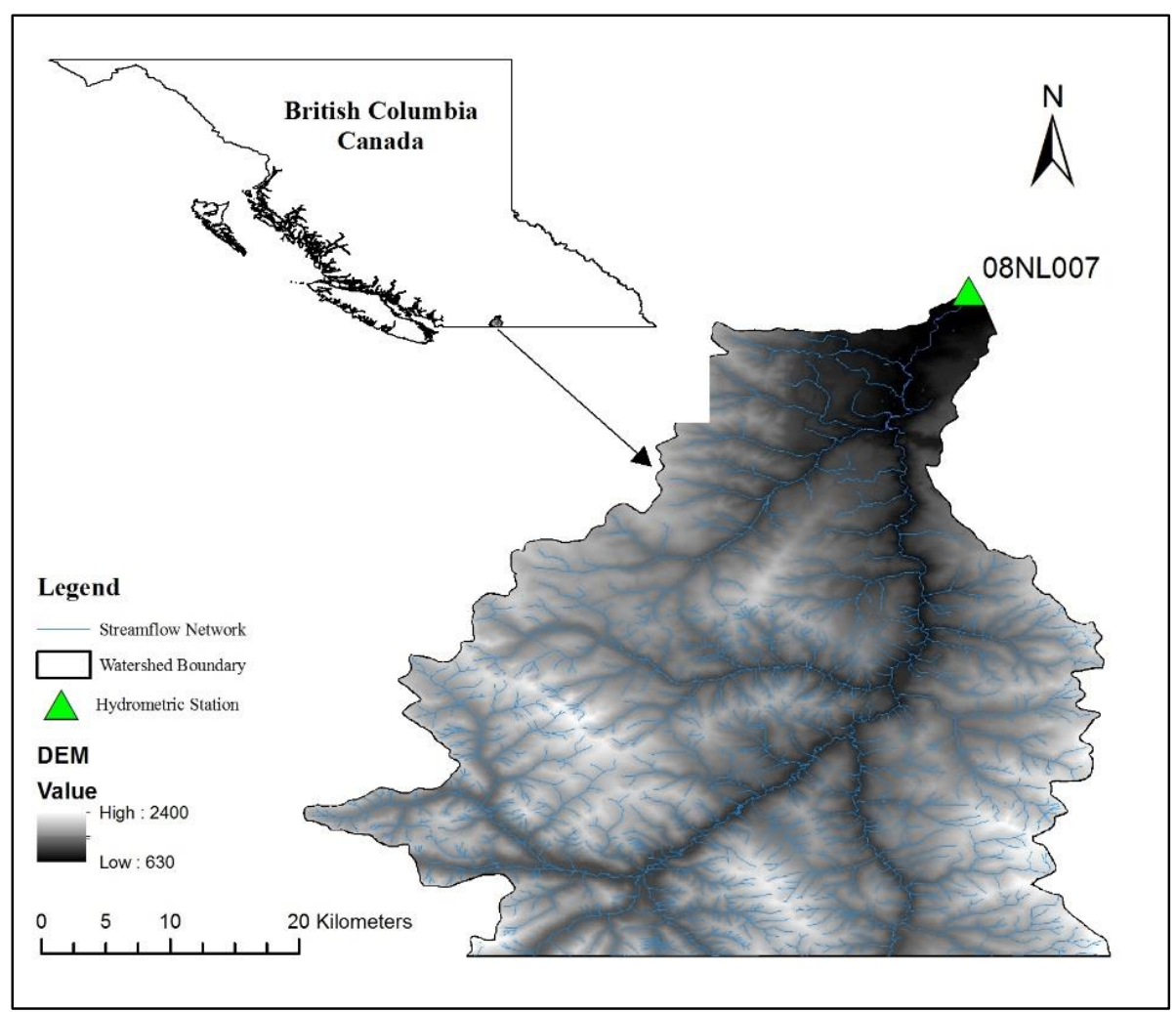

Figure 1. Location, streamflow network, and elevations of the study watershed with the total area of 1810 $\mathrm{km}^{2}$, of which $466 \mathrm{~km}^{2}$ is in USA 
Hydrol. Earth Syst. Sci. Discuss., doi:10.5194/hess-2016-291, 2016

Manuscript under review for journal Hydrol. Earth Syst. Sci.

Published: 20 June 2016

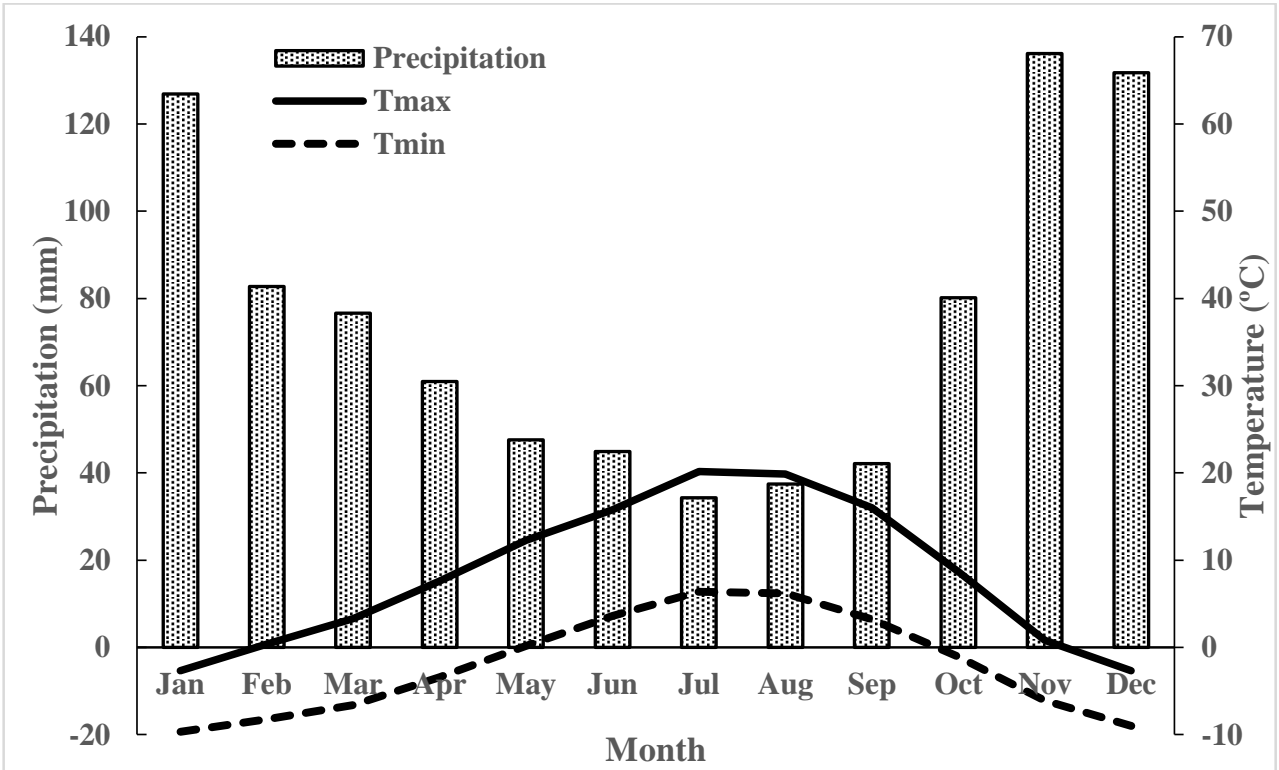

Figure 2. Long-term (1954-2013) average monthly precipitation, and monthly maximum and minimum temperatures in the Upper Similkameen River watershed 
Hydrol. Earth Syst. Sci. Discuss., doi:10.5194/hess-2016-291, 2016

Manuscript under review for journal Hydrol. Earth Syst. Sci.

Published: 20 June 2016

(c) Author(s) 2016. CC-BY 3.0 License.

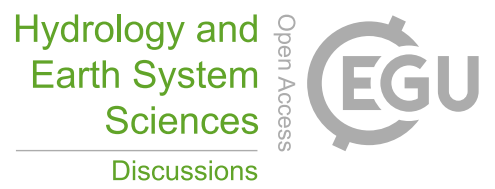

(c) $\underset{\mathrm{BV}}{\mathrm{BV}}$

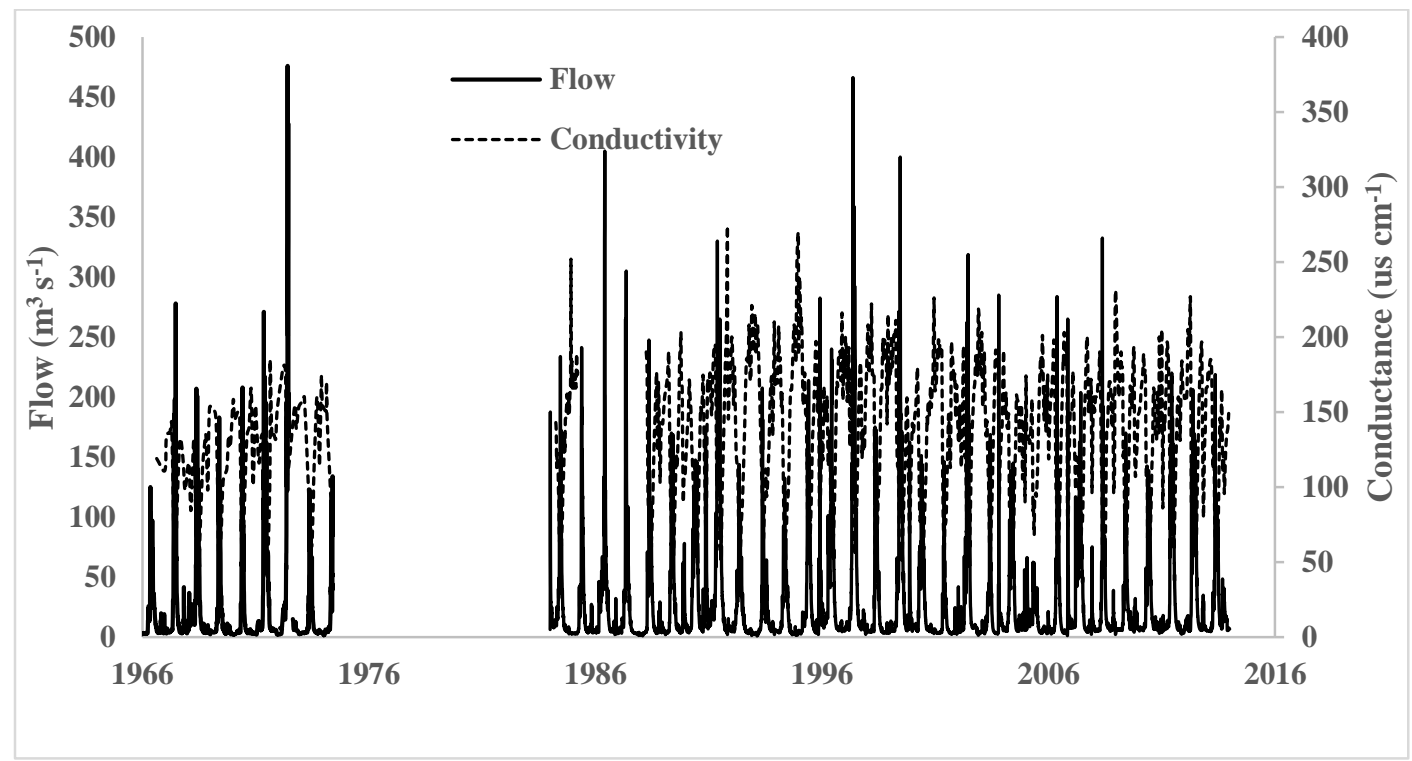

Figure 3. Long term (1966-2013) discrete conductivity measurement and continuous streamflow discharge data in Upper Similkameen River watershed. 


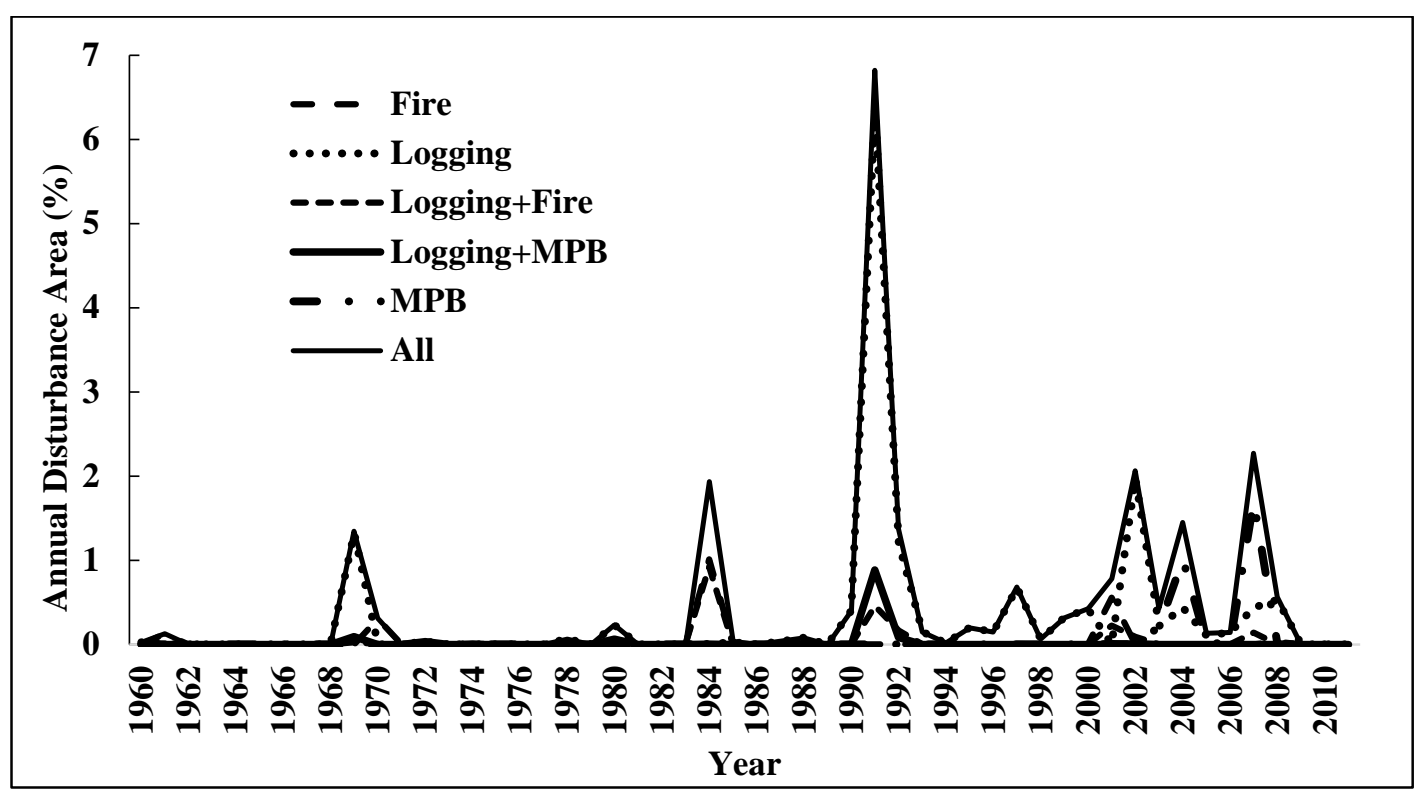

Figure 4. Annual disturbed area (\% of the watershed) in the Upper Similkameen River watershed from 1960 to 2011. 
Hydrol. Earth Syst. Sci. Discuss., doi:10.5194/hess-2016-291, 2016

Manuscript under review for journal Hydrol. Earth Syst. Sci.

Published: 20 June 2016

(c) Author(s) 2016. CC-BY 3.0 License.

(c) (i)

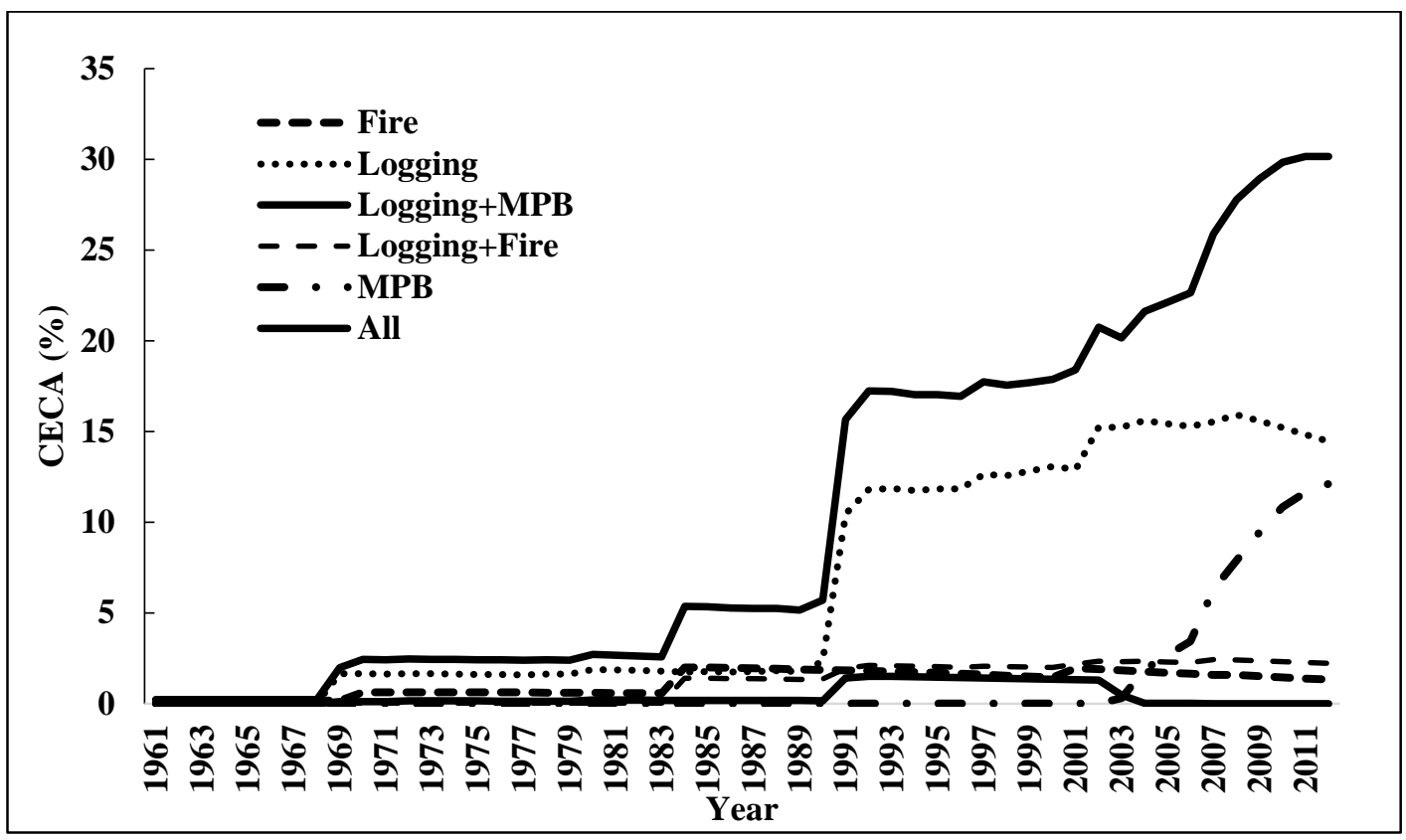

Figure 5. Cumulative Equivalent Clear-cut Area (CECA) in the Upper Similkameen River watershed from 1960 to 2011. 
Hydrol. Earth Syst. Sci. Discuss., doi:10.5194/hess-2016-291, 2016

Manuscript under review for journal Hydrol. Earth Syst. Sci.

Published: 20 June 2016

(c) Author(s) 2016. CC-BY 3.0 License.
Hydrology and

Discussions

(c) $\underset{\mathrm{By}}{\mathrm{B}}$

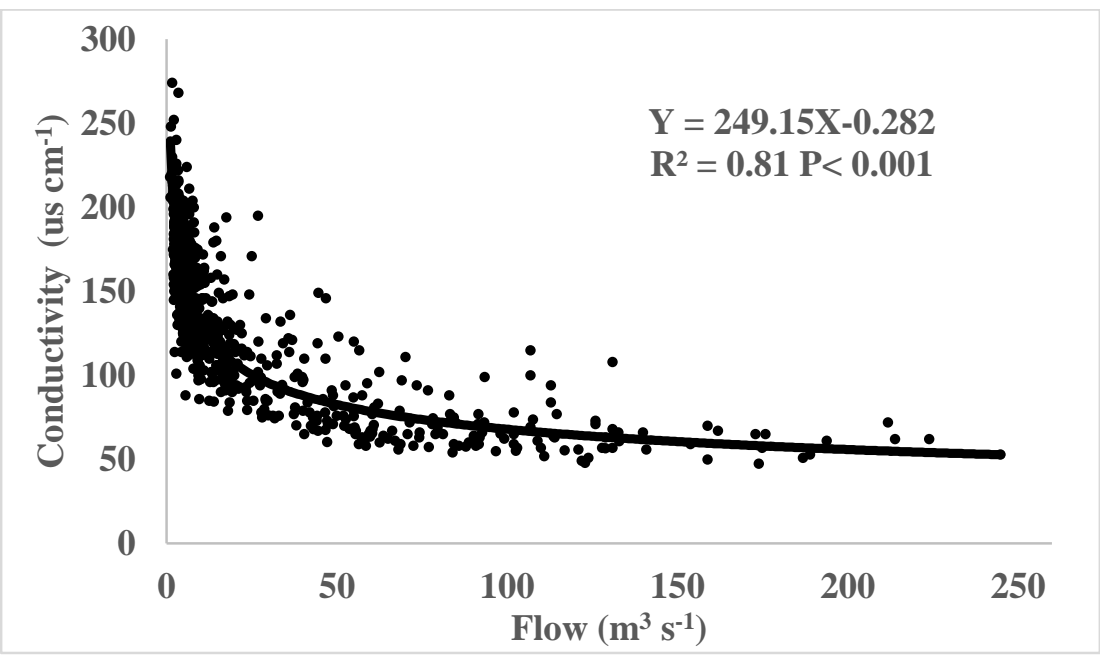

Figure 6. The relationship between streamflow conductivity (Y) and streamflow discharge (X) in

Similkameen River at Princeton.

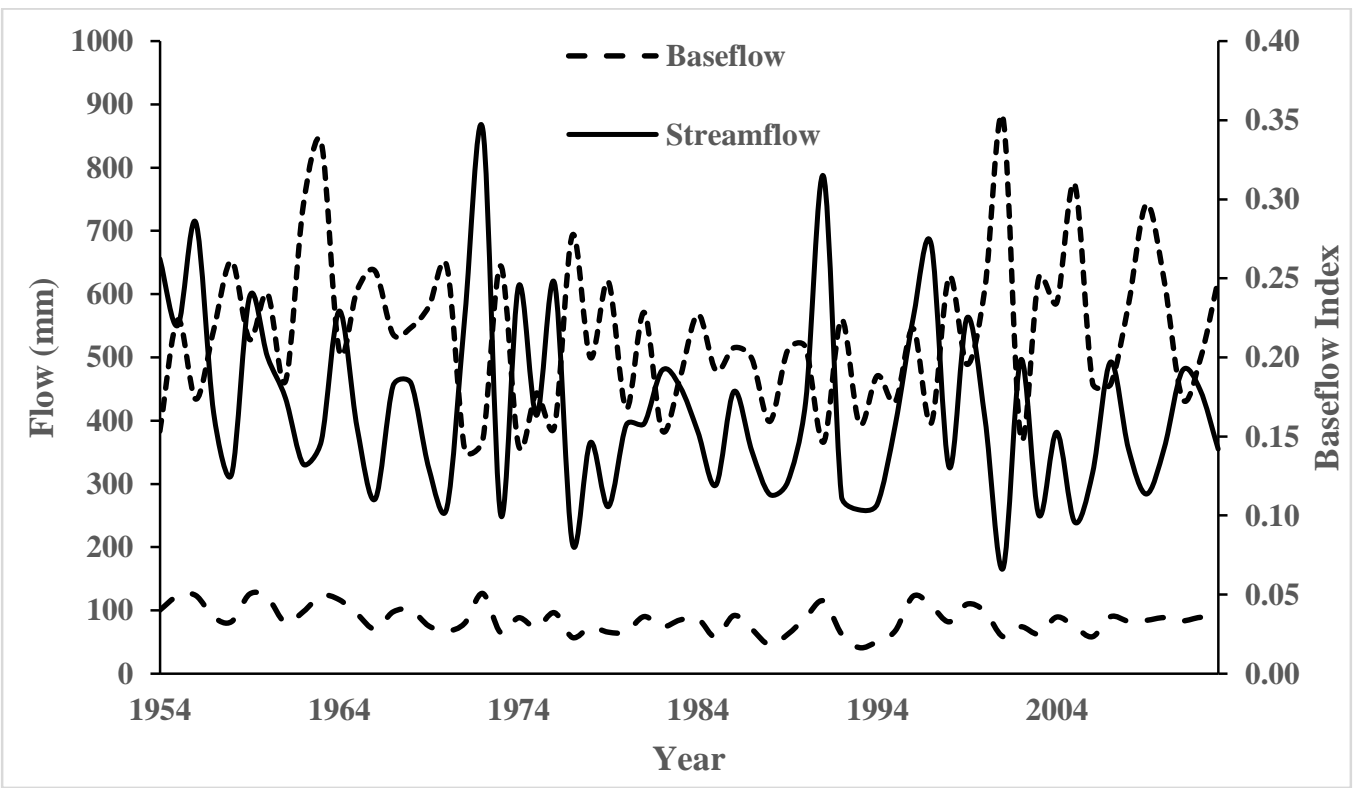

Figure 7. Long-term annual mean streamflow, baseflow, and baseflow index (BFI) in the Upper Similkameen River watershed at Princeton from 1954 to 2013. 
Hydrol. Earth Syst. Sci. Discuss., doi:10.5194/hess-2016-291, 2016

Manuscript under review for journal Hydrol. Earth Syst. Sci.

Published: 20 June 2016

(c) Author(s) 2016. CC-BY 3.0 License.

(c) (i)
Hydrology and

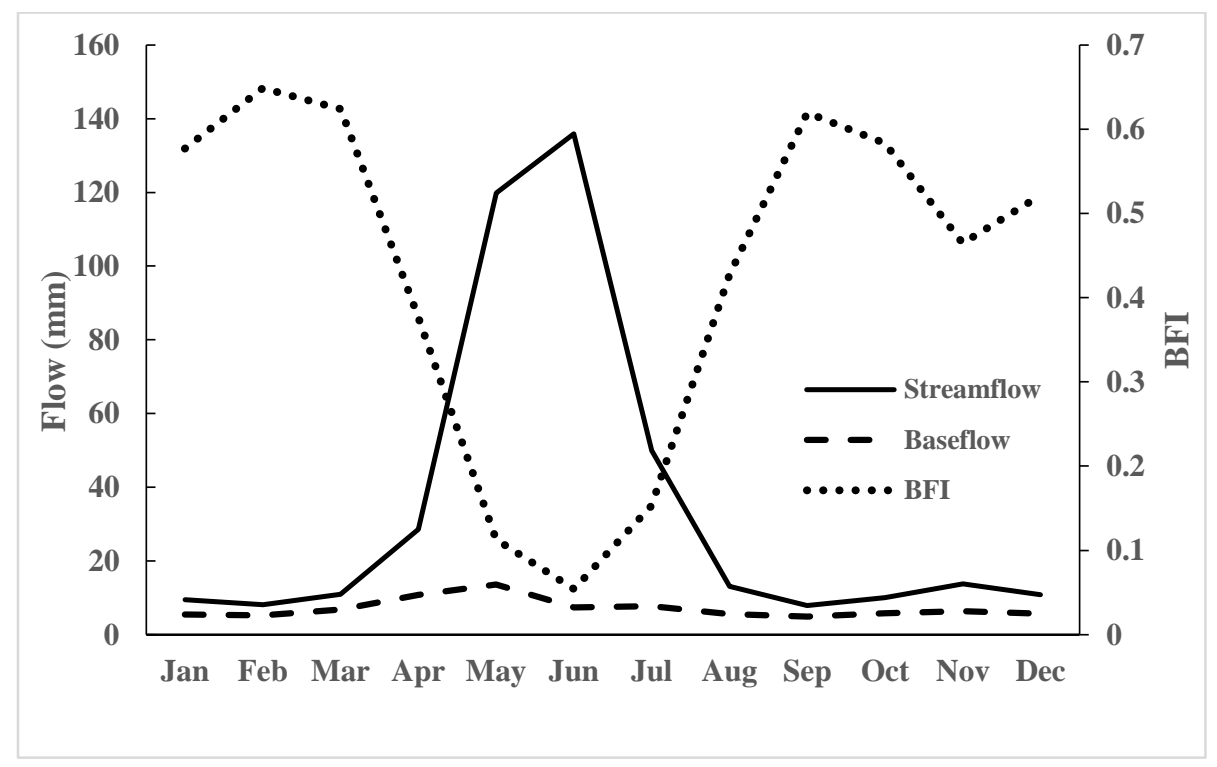

Figure 8. Long-term monthly streamflow, baseflow, and baseflow index (BFI) in the Upper Similkameen River watershed at Princeton from 1954 to 2013.

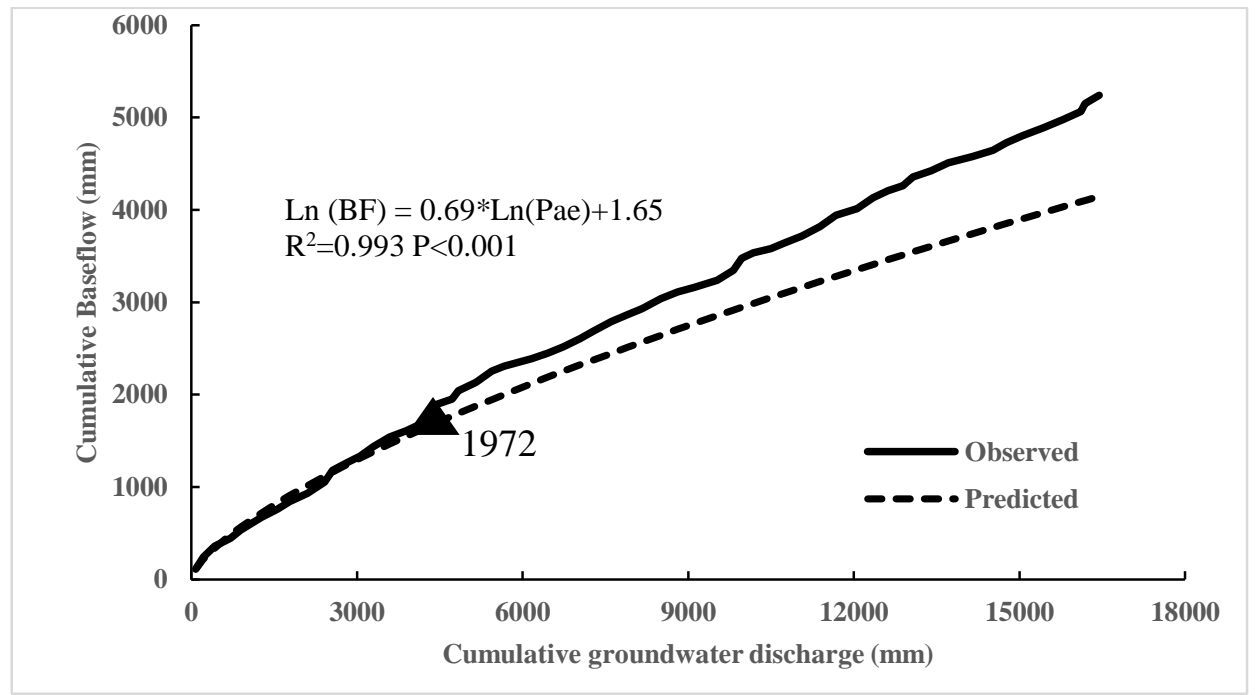

5 Figure 9. Modified Double Mass Curve of cumulative annual baseflow vs. cumulative groundwater discharge 
Hydrol. Earth Syst. Sci. Discuss., doi:10.5194/hess-2016-291, 2016

Manuscript under review for journal Hydrol. Earth Syst. Sci.

Published: 20 June 2016

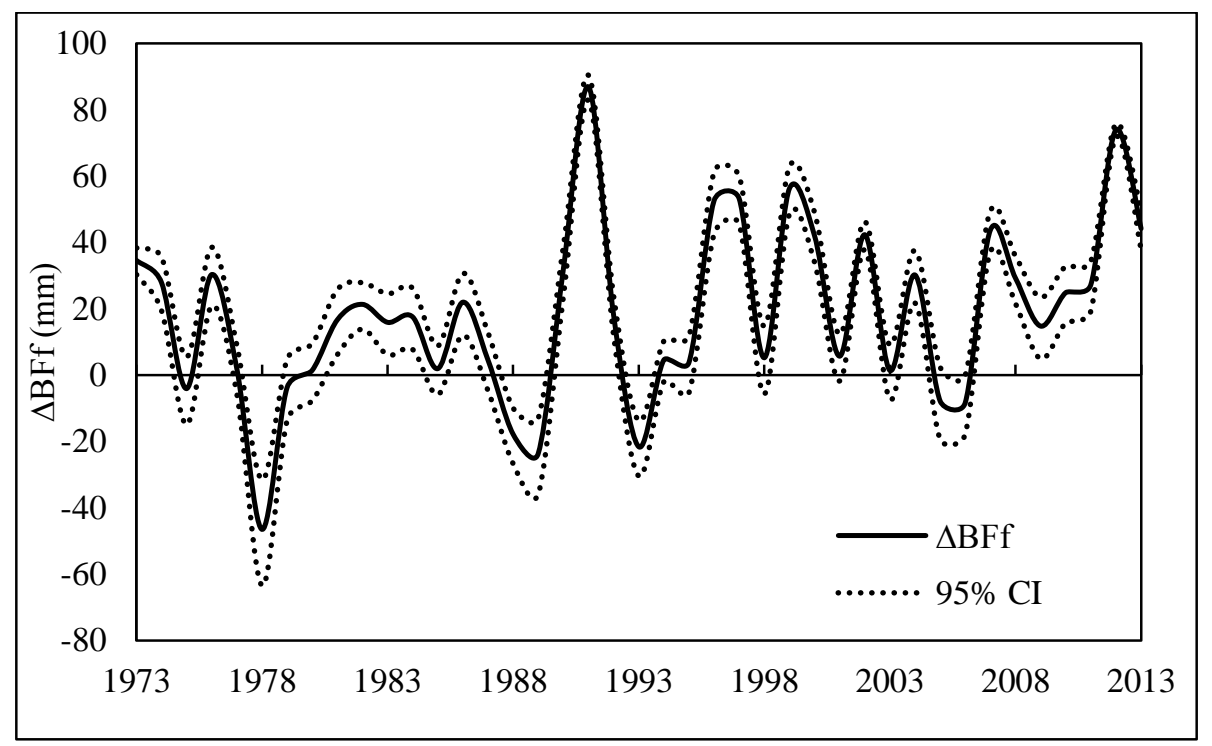

Figure 10. Annual variations of the effects of forest disturbance on annual baseflow in the Upper Similkameen River watershed from 1973 to 2013. 
Hydrol. Earth Syst. Sci. Discuss., doi:10.5194/hess-2016-291, 2016

Manuscript under review for journal Hydrol. Earth Syst. Sci.

Published: 20 June 2016

(c) Author(s) 2016. CC-BY 3.0 License.

Table 1. Summary of the regression model for conductivity estimation

\begin{tabular}{lllll}
\hline Parameters & Estimate & Std. Error & T value & $\mathrm{P}$ \\
Intercept & -2.334 & 0.867 & -2.693 & $<0.01$ \\
Ln Q & -0.243 & 0.012 & -19.684 & $<0.001$ \\
$\mathrm{~T}$ & 0.004 & 0.000 & 8.865 & $<0.001$ \\
$\sin (2 \pi \mathrm{T})$ & 0.054 & 0.007 & 7.552 & $<0.001$ \\
$\cos (2 \pi \mathrm{T})$ & 0.004 & 0.009 & 0.434 & 0.665 \\
$\sin (4 \pi \mathrm{T})$ & -0.027 & 0.007 & -3.801 & $<0.001$ \\
$\cos (4 \pi \mathrm{T})$ & -0.026 & 0.007 & -3.527 & $<0.001$ \\
FA_1 year & 0.068 & 0.019 & 3.648 & $<0.001$ \\
FA_30 days & -0.132 & 0.026 & -4.994 & $<0.001$ \\
FA_1 day & 0.037 & 0.032 & 1.153 & 0.249 \\
\hline
\end{tabular}


Hydrol. Earth Syst. Sci. Discuss., doi:10.5194/hess-2016-291, 2016

Manuscript under review for journal Hydrol. Earth Syst. Sci.

Published: 20 June 2016

(c) Author(s) 2016. CC-BY 3.0 License.

(c) (1)
Hydrology and

Table 2. Cross-correlations between cumulative equivalent clear-cut area (CECA) and hydrological variables

\begin{tabular}{llll}
\hline Hydrological Variables & \multicolumn{3}{l}{ Cross-correlation } \\
& ARIMA Model & Cross-correlation coefficients & Lags \\
\cline { 2 - 3 } & & & -7 \\
\hline Annual mean flow & Ln, $(0,1,1)$, Lag1 & $\mathbf{0 . 3 4} *$ & -7 \\
\hline Annual mean baseflow & Ln, $(0,1,1)$, Lag1 & $\mathbf{0 . 4 3} *$ & -7 \\
\hline Spring mean baseflow & Ln, $(1,1,1)$, Lag1 & $\mathbf{0 . 3 7 *}$ & -1 \\
\hline Summer mean baseflow & Ln, $(2,1,1)$, Lag1 & $\mathbf{- 0 . 3 9 *}$ & -10 \\
& & $\mathbf{- 0 . 3 8 *}$ & 0
\end{tabular}

ARIMA model for CECA, model structure: Ln, $(0,2,1)$ Lag 1; 
Hydrol. Earth Syst. Sci. Discuss., doi:10.5194/hess-2016-291, 2016

Manuscript under review for journal Hydrol. Earth Syst. Sci.

Published: 20 June 2016

(c) Author(s) 2016. CC-BY 3.0 License.

(c) (1)
Hydrology and

Table 3. ARIMA Intervention for the slope of MDMC for baseflow

\begin{tabular}{lllll}
\hline & & \multicolumn{3}{c}{ Parameters Estimation } \\
\cline { 3 - 5 } Model Input & Model Structure & Intervention & $\mathrm{Q}(1)$ & $\Omega(1)$ \\
& & Type & & \\
\hline Slope of MDMC & Interrupted ARIMA: $(0,3,1)$, & Abrupt & $0.96(\mathrm{P}<0.001)$ & $0.011(\mathrm{P}=$ \\
for baseflow & Intervention at year 1972 & Permanent & & $0.02)$ \\
\hline
\end{tabular}

Table 4. Relative contributions of forest disturbance and climate variability to annual baseflow in the $5 \quad$ Upper Similkameen River watershed from 1973 to 2013.

\begin{tabular}{lllllllll}
\hline Baseflow & $\Delta \mathrm{BF}(\mathrm{mm})$ & $\Delta \mathrm{BF}_{\mathrm{f}}(\mathrm{mm})$ & $\Delta \mathrm{BF}_{\mathrm{f}} / \mathrm{BF}(\%)$ & $\Delta \mathrm{BF}_{\mathrm{c}}(\mathrm{mm})$ & $\Delta \mathrm{BF}_{\mathrm{c}} / \mathrm{BF}(\%)$ & $\mathrm{R}_{\mathrm{f}}(\%)$ & $\mathrm{R}_{\mathrm{c}}(\%)$ & $\begin{array}{l}\mathrm{CECA} \\
(\%)\end{array}$ \\
\hline $1973-1982$ & -5.3 & 8 & 12.0 & -13.3 & -19.9 & 37.5 & 62.5 & 2.31 \\
$1983-1992$ & -1.1 & 15.8 & 26.1 & -16.9 & -27.9 & 48.3 & 51.7 & 5.48 \\
$1993-2002$ & 1.1 & 24.4 & 43.0 & -23.3 & -41.1 & 51.2 & 48.8 & 14.33 \\
$2003-2013$ & 1.3 & 24.9 & 41.1 & -23.6 & -38.9 & 51.3 & 48.7 & 23.94 \\
$1973-2013$ & -0.9 & 18.4 & 30.8 & -19.4 & -32.4 & 48.8 & 51.2 & 11.82 \\
\hline
\end{tabular}

